\title{
Penanaman Nilai-Nilai Pancasila dalam Pendidikan di Pondok Pesantren
}

\section{Ricky Habibullah}

Fakultas Ilmu Tarbiyah dan Keguruan Universitas Islam Negeri

Sunan Kalijaga Yogyakarta

rickyhabibulloho@gmail.com

\section{Diaz Gandara Rustam}

Fakultas Ilmu Tarbiyah dan Keguruan Universitas Islam Negeri

Sunan Kalijaga Yogyakarta

dgro6120o@gmail.com

\section{Abstract}

This study will discuss the urgency of Pancasila values in the context of life. The role of Islamic boarding schools, which has proven to be effective in educating Pancasila values. Pondok Pesantren Tremas is one of the Pesantren that is consistent in internalizing the values of Pancasila in education, both educational activities, such as those visualized in wetonan, roan and so on. This research is a Field Research, which is to get data directly from respondents by means of observation, interview, documentation and triangulation. Pondok Pesantren Tremas Arjosari, Pacitan, East Java, especially in educating Pancasila values by strengthening the basis of activities, both formally, non-formally and informally, which contain the substance of Pancasila values. Such as the activities of the santri ceremony, ngipa, roan and several other activities. As well as those that contain the values of love for the country, the value of tolerance, togetherness, divinity, mutual cooperation.

Keywords: Pancasila values, Islamic boarding schools, education

\section{Abstrak}

Kajian ini akan membahas urgensi nilai-nilai Pancasila dalam konteks kehidupan. Peran Pesantren yang terbukti efektif dalam mendidik nilai-nilai Pancasila. Pondok Pesantren Tremas merupakan salah satu Pesantren yang konsisten menginternalisasikan nilai-nilai Pancasila dalam pendidikan, baik kegiatan pendidikan seperti yang divisualisasikan dalam wetonan, roan dan lain sebagainya. Penelitian ini merupakan Penelitian Lapangan, yaitu mendapatkan data langsung dari responden dengan cara observasi, wawancara, dokumentasi dan 
triangulasi. Pondok Pesantren Tremas Arjosari, Pacitan, Jawa Timur khususnya dalam mendidik nilai-nilai Pancasila dengan memperkuat landasan kegiatan baik formal, nonformal maupun informal yang mengandung substansi nilai-nilai Pancasila. Seperti kegiatan upacara santri, ngipa, roan dan beberapa kegiatan lainnya. Serta yang mengandung nilai cinta tanah air, nilai toleransi, kebersamaan, ketuhanan, gotong royong.

Kata kunci: Nilai-nilai Pancasila, Pondok Pesantren, Pendidikan

\section{Pendahuluan}

Lima sila dalam Pancasila yaitu: Ketuhanan yang Maha Esa, Kemanusiaan yang adil dan beradab, Persatuan Indonesia, Kerakyatan yang dipimpin oleh kebijaksanaan dalam permusyawaratan / perwakilan, Keadilan sosial bagi seluruh rakyat Indonesia. ${ }^{1}$ Unsur-unsur Pancasila tersebut, sebelum secara langsung dirumuskan menjadi falsafah dasar Negara, didalamnya tersirat nilai-nila adat istiadat, nilai kebudayaan serta nilai-nilai relegius. Nilai-nilai tersebut menjadi pedoman dalam memecahkan

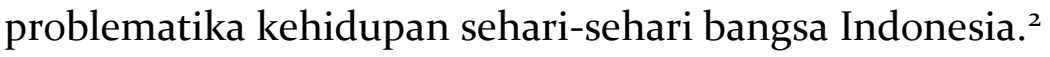

Rentannya pemuda terhadap aksi kekerasan dan radikalisme patut menjadi keprihatinan bersama. Banyak faktor yang menyebabkan para pemuda terseret ke dalam hal tersebut, mulai dari kemiskinan, kurangnya pendidikan agama yang damai, gencarnya infiltrasi kelompok radikal, lemahnya semangat kebangsaan, kurangnya pendidikan kewarganegaraan, kurangnya keteladanan, dan tergerusnya nilai kearifan lokal oleh arus modernitas negatif. 3

Pesantren sudah sejak lama menjadi lembaga yang membentuk watak dan peradaban bangsa serta mencerdaskan kehidupan bangsa yang berbasis pada keimanan dan ketakwaan

${ }^{1}$ Ibid. hlm. 144

${ }^{2}$ Kaelan, Pendidikan Pancasila Yuridis Kenegaraan, (Yogyakarta: Paradigma Ofset,1998), hlm,55

3 Ibid. 
kepada Allah SWT serta akhlak mulia. Pesantren sekarang mampu memerankan diri sebagai benteng pertahanan dari imperialisme budaya yang begitu kuat menghegemoni kehidupan masyarakat, khususnya di perkotaan. Perkembangan Pesantren dengan sistem pendidikannya mampu menyejajarkan diri dengan pendidikan pada umumnya, sehingga tidak mungkin negara ini dipisahkan dari Pesantren 4 .

Pondok Pesantren Tremas Arjosari Pacitan Jawa Timur merupakan salah satu pondok Pesantren tertua di Indonesia yang menanamkan nilai-nilai Pancasila dalam edukasi, baik dalam amaliyah maupun thariqoh. Kegiatan yang menjadi mediasi untuk menanamkan nilai-nilai Pancasila terbagi tiga, yaitu kegiatan formal, nonformal, dan informal.

Dalam artikel ini, peneliti akan mengkaji beberapa problematika yang dirasa harus dikaji lebih mendalam, terkait: (1) Penanaman Nilai-Nilai Pancasila dalam Pendidikan di Pondok Pesantren Tremas Arjosari Pacitan Jawa Timur, (2) Faktor pendukung dan penghambat dalam Penanaman Nilai-Nilai Pancasila dalam Pendidikan di Pondok Pesantren Tremas Arjosari Pacitan Jawa Timur.

\section{Metode}

Penelitian ini merupakan jenis penelitian field research dengan menggunakan metode kualitatif. Metode pengumpulan data untuk bahan penelitian dengan cara observasi, wawancara, dan dokumentasi. Kemudian, untuk analisa data menggunakan metode reduksi data dan melakukan triangulasi data untuk menguji keabsahan data. Pondok Pesantren Tremas Arjosari Pacitan Jawa Timur, merupakan subjek penelitian kali ini. Untuk melihat bentuk penanaman nilai-nilai Pancasila di Pondok Pesantren Tremas, dilakukan pengamatan melalui berbagai

\footnotetext{
${ }^{4}$ Ibid., hal. 10
} 
kegiatan yang dilakukan, seperti ngaji wetonan, roan, dan sebagainya.

\section{Hasil Penelitian dan Pembahasan}

Penanaman Nilai-nilai Pancasila dalam Pendidikan di Pondok Pesantren Tremas Arjosari Pacitan Jawa Timur

Bentuk-bentuk Kegiatan Penanaman nilai-nilai Pancasila dalam Pendidikan di Pondok Pesantren Tremas Arjosari Pacitan Jawa Timur pada dasarnya berkaitan erat dengan bentuk kegiatan yang ada di pondok. Hubungan antara keduanya saling berkesinambungan. Berdasarkan hasil penelitian melalui wawancara, observasi, dan dokumentasi yang dilakukan oleh peneliti di Pondok Pesantren Tremas Arjosari Pacitan Jawa Timur maka diperoleh data-data seperti berikut ini.

Pondok Pesantren Tremas Arjosari Pacitan Jawa Timur melaksanakan berbagai macam pendidikan, diantaranya adalah Pendidikan formal, nonformal dan informal. 5 Pendidikan formal Pondok Pesantren Tremas Pacitan Arjosari Jawa Timur menerapkan sistem KBM khalayak sekolah umum lainya, dari jenjamg MTs sampai MA. Kegiatan Belajar Mengajar (KBM) merupakan salah satu bentuk mediasi bagi pondok pesantren untuk melakukan penanaman nilai-nilai Pancasila kepada setiap santri. Ada beberapa substansi dan bahan ajar yang disampaikan oleh pengajar pondok, diantaranya:

a. Kitab Idzotun Nasyyin,

Kitab Idzotun Nasyiin diajarkan kepada santri yang sudah berjenjang 1 sampai 3 Aliyah. Menjadi kewajiban bagi santri untuk memahami subtansi kata-perkata yang ada didalam kitab tersebut. Guru membaca kitab tersebut dengan menterjemahkannya kedalam bahasa Jawa dan santri

${ }^{5}$ Hasil wawancara dengan wawancara dengan $\mathrm{KH}$, Abdilah Nawawi LC pada hari Jumat tanggal 30 Oktober 2020 jam 21.40 WIB di Pondok Pesantren Tremas 
memaknainya dengan Arab Pegon. Di dalam proses pembelajarannya, para santri mendengarkan dengan khidmah tanpa ada suara ataupun keributan yang di luar KBM di kelas; sehingga Ustad dalam menerangkan kitab Idzotun Nasyiin didengarkan oleh santri dengan secara jelas.

Kekhasan Guru ataupun kyai dalam mengajarkan kitab Idhotun Nasyiin terhadap santri kelas 1-3 Aliah adalah di dalam menerangkan $\mathrm{BAB}$ atau pasal yang ada ada di dalam kitab tersebut. Fasal-fasal yang substansi mengandung nilai-nilai Pancasila dijelaskan oleh guru dengan contoh sederhana-santri yang belum paham langsung bertanya terhadap Guru terkait dengan materi yang telah disampaikan.

Hal-hal tersebut menjadikan proses pembelajaran menjadi kondusif-kefokusan antara santri dan guru menjadi kesuksesan dalam memahami pasal-pasal yang ada di dalam Kitab Idhotun Nasyiin, berikut ini beberapa bab yang mengandung substansi nilai-nilai Pancasila di dalam Kitab Idhotun Nasyiin: ${ }^{6}$

\section{Harapan}

Andai kata tidak ada harapan maka tidak ada orang yang berusaha mencapai cita-citanya, dan tidak ada orang untuk mengajak kepada cinta tanah air. Saya tidak pernah melihat orang yang bekerja kecuali ia telah yakin bahwa pekerjaannya memiliki hasil yang baik dan bisa diharapkan manfaatnya, baik untuk diri sendiri atau untuk kalangan umum. kehilangan sifat Rojae merupakan sebuah penyakit yang bersarang dalam banyak orang. Orang-orang yang bekerja dengan semangat benar-benar mengerti bahwa harapan keberhasilan merupakan pendorong utama untuk maju dan merupakan sebab utama keberhasilan.

${ }^{6}$ Hasil wawancara dengan Ustad Mashuri pada hari Senin tanggal 1 November 2020 jam 17.10 WIB di Pondok Pesantren Tremas 


\section{Tolong Menolong}

Jadilah kalian orang yang membantu orang lain, gemarlah berbuat baik kepada orang lainsudah tentu orang lain akan berbuat baik kepadamu. Wahai generasi muda kita tidak diciptakan kecuali agar kita saling tolong menolong memberantas kesengsaraan yang menimpa kita dan saling bahu membahu baik dalam kedaaan senang atau sengsara dan bekerja sama mengenyahkan penderitaan yang menimpa umat.

Kedermawanan

Harta kekayaan seperti halnya kekuasann itu berfungsi sebagai pelayan bagi manusia ketika terdesak oleh kebutuhan. Harta kekayaan harus disertai dengan kedermawanan, sama sekali tidak ada manfaat dan kebaikan jika pemiliknya kikir atau boros. Sederhana atau sikap tengah-tengah bagi orang yang kaya yaitu kedermawanan hal itu bisa mendatangkan kebahagiaan berupa harta. Dengan demikian bersikap sedang atau mengambil jalan tengah dalam segala permasalahan itu menyebabkan terhindar dari malapetaka. Oleh sebab itu hendaklah seseorang menginfakkan hartanya untuk kepentingan diri sendiri, keluarga dan orang-orang yang membutuhkan bantuan dengan tidak berlebihan dan tidak pula bakhil. (Al Ghalayani, 1913:115)

Penjelasan mengenai tiga bab diatas merupakan hasil dari wawancara dengan ustadz Abror di pondok Pesantren Tremas Arjosari Pacitan Jawa Timur.

"kitab idzotun nasyiin mengandung nilai-nilai pancasila yang tertulis dengan diksi kata yang subtansinya sama" seperti taawun (tolong menolong), dermawan dan roja (pengharap) semuanya terkandung dalam sila ke lima, sila pertama dan sila ketiga"

Demikian, dapat disimpulkan bahwa Kitab Idzotun Nasyiin mengandung nilai-nilai pancasila, termasuk salah satu pengajar kitab tersebut KH Fuad Habib Dimyati, beliau mengajarkan dengan 
menggunakan makna pegon dan memberikam contoh dengan mudah seperti tolong menolong "santri itu harus saling tolong menolong agar hidup kemudian hari tidak sendirian" dan banyak lagi contoh yang beliau utarakan. Sehingga subtansi kitab Idzotun Nasyiin mudah difahami oleh para santri. ${ }^{7}$

b. PKN

Materi PKN adalah salah satu hal fundamental dalam mengajarkan kecintaan terhadap keutuhan Negara Kesatuan Republik Indonesia. Salah satu materinya adalah pancasila dan pembukaan UUD $45 .{ }^{8}$ Kutipan dari wawancara KH Muhaamad: "pondok Pesantren tremas arjosari pacitan jawa timur didalam pengaajaran formalnya tidak lepas dalam memberikan pemahaman cinta tanah air dan nasionalisme terhadap santri, bahkan dalam keseharian dan aktivitas santri dituntut untuk bisa mengamalkan nilai nilai pancasila dengan istiqomah, seperti menghargai pendapat orang lain,gotong royong dan sebagainya. Jadi santri pondok tremas pasti mencintai tanah air dan menghargai perbedaan."

Pendidikan Non formal yang diterapkan oleh Pondok Pesantren Tremas Pacitan Arjosari Jawa Timur, secara berkesinambungan berhubungan dengan beberapa kegiatan yang menunjang pengetahuan santri dan karakter, seperti kegiatan ngaji wetonan, PHBI dan Bahstul Masail, serta kegiatan lainya yang menunjang santri untuk memiliki berbagai keterampilan yang ada didalam dirinya. Pendidikan informal yang ada di Pondok Pesantren Tremas Arjosari Pacitan Jawa Timur lebih menekankan terhadap rasa

7 Hasil wawancara dengan KH Abdilah Nawawi LC pada hari Jumat tanggal 30 Oktober 2020 jam 21,50 WIB di Pondok Pesantren Tremas

${ }^{8}$ Hasil wawancara dengan KH Muhammad pada hari Jumat tanggal 30 Oktober 2020, jam 14,10 WIB di Pondok Pesantren Tremas 
kekeluargaan dan tradisi, seperti kegiatan roan, ngipa dan lainlain. ${ }^{9}$

1. Non formal

a. Ngaji wetonan/bandongan

Pesantren juga kerap menggunakan metode bandongan atau bandungan. Istilah bandungan berasal dari bahasa Sunda ngabandungan yang berarti memperhatikan secara saksama atau menyimak. Dengan metode ini, para santri akan belajar dengan menyimak secara kolektif. Namun, dalam bahasa Jawa, bandongan disebutkan juga berasal dari kata bandong, yang artinya pergi berbondong-bondong. Hal ini karena bandongan dilangsungkan dengan peserta dalam jumlah yang relatif besar. ${ }^{10}$

Penulis buku Tradisi Pesantren Zamakhsyari Dhofier mengatakan, dalam menggunakan sistem ini, sekelompok murid yang terdiri antara 5 sampai 500 orang mendengarkan seorang guru yang membaca, menerjemahkan, menerangkan, dan sering kali mengulas buku-buku Islam dalam bahasa Arab. Setiap murid memperhatikan bukunya sendiri dan membuat catatan-catatan (baik arti maupun keterangan) tentang kata-kata atau buah pikiran yang sulit.

Metode kedua ini oleh beberapa kalangan disebut juga wetonan, yang berasal dari kata wektu yang berarti waktu. Hal ini karena pengajian-pengajian tersebut hanya diberikan pada waktu-waktu tertentu, yaitu sebelum atau sesudah melakukan shalat fardhu di masjid atau mushala Pesantren.

9 Hasil wawancara dengan Ustadz Abror pada hari Senin tanggal 1 November 2020 jam 20.30 WIB di Pondok Pesantren Tremas

${ }^{10}$ Hafidz Muftisany, "Sorogan Dan Bandongan Metode Khas Pesantren," Republika, April 8, 2016, https://republika.co.id/berita/o5ar464/sorogan-dan-bandonganmetode-khas-pesantren. 
Dalam mempraktikkan metode ini, seorang kiai akan membacakan kitab kuning dan menerjemahkannya ke dalam bahasa ibu, seperti ke bahasa Madura, Sunda, atau Jawa. Kemudian, santri menuliskan terjemahan kata demi kata seperti yang disampaikan oleh kiai tersebut. Sistem penerjemahan disampaikan sedemikian rupa sehingga para santri mudah mengetahui baik arti maupun fungsi kata dalam suatu rangkaian kalimat dalam kitab kuning tersebut.

Metode bandongan adalah metode transfer keilmuan atau proses belajar mengajar yang ada di Pesantren yang mengajarkan khusus pada kitab kuning. Kiai tersebut membacakan, menerjemah, dan menerangkannya. Sedangkan, santri atau murid mendengarkan, menyimak, dan mencatat apa yang disampaikan oleh kiai yang memberi pengajian tersebut.

Bedasarkan istilah diatas Pondok Pesantren Tremas Arjosari Pacitan Jawa Timur lebih menggunakan bahasa ngaji wetonan, setiap hari pasti ada jadwal, yang pasti selesai pelaksanaan kegiatan formal sseperti masuk sekolah dipagi hari sampai siang dan sebagainya. ${ }^{11}$

Mengutip dari wawancara salah satu keluarga dalem $\mathrm{KH}$ Abdilah Nawawi:

" ngaji wetonan memiliki prinsip yang baik, mengajarkan kepada para santri untuk tepat waktu, duduk bersama, mendengarkan secara kolektif dan canda tawa bersama, sehingga ikatan tali emosional antara para santri dan pengajar terbentuk, membuat berjalanya kegiatan mengajar semakin kondusif, samtri juga lebih mudah memahami dan mengerti, beliau mengatakan bahwa ngaji wetonan mengandung nilai-nilai pancasila,

${ }^{11}$ Hasil wawancara dengan KH Muad Haris Dimyati pada hari Sabtu tanggal 31 oktober 2020 jam 21,54 WIB di Pondok Pesantren Tremas 
yaitu dalam prinsip kebersamaan yang urgensinya adalah persatuan indonesia"12

Bedasarkan wawancara tersebut, jelas Pondok Pesantren Tremas Arjosari Pacitan Jawa Timur konstinten dalam mengedukasi nilai nilai pancasila dalam pendindikan terhadap para santri, membuat astmofer dilingkungan pondok dalam suasana Nasionalisme dan cinta Tanah Air. ${ }^{13}$

b. Bahstul Masail

Bahtsul Masail sebuah kegiatan yang ada di Pondok Pesantren Tremas Arjosari Pacitan Jawa Timur, bentuk kegiatanya adalah tanya jawab antar santri berlangsung ramai. Semua saling melontarkan pertanyaan masing-masing. Riuh suara peserta pun tidak terelakkan. Entah itu berasal dari peserta yang menjawab atau para santri lain yang ikut-ikutan berteriak untuk sekedar meramaikan acara Seringkali saat memasuki season pembahasan masalah.

Santri terlihat gaduh dan ribut saat berdebat argumen. Itulah suasana Bahtsul Masail yang kental akan perdebatan argumen. Mereka akan keukeh meyakini pendapat mereka sesuai dengan takbir, dasar-dasar, dan dalil-dalil yang telah diambilnya. Dan itulah yang menarik dari Bahtsul Masail. ${ }^{14}$

Bahtsul Masail yang didalamnya membahas berbagai persoalan keagamaan digelar sebagai upaya untuk terus menjaga ruh Pesantren. Bahtsul Masail dilakukan sebagai sarana untuk menyegarkan kembali pelajaran-pelajaran yang pernah diajarkan di kelas. Para santri dilatih untuk cipta,1994).

${ }^{12}$ Burhanudin salam, Filsafat Pancasialisme, (Bandung: Rineka

${ }^{13}$ Fani Pradana, Impelementasi nilai-nilai pancasila sila kemanusiaan yang adil dan beradab dalam kehidupan santri di pondok Pesantren muhamadiyah desa lemah, Universitas Muhammadiyah,2014.

${ }^{14}$ M Fathurrozi, "Bahtsul Masail; Pendapat Siapa Yang Paling Kuat,” Pondoktremas.com, n.d., https://pondoktremas.com/bahtsul-masailpendapat-siapa-yang-paling-kuat/. 
berani mengungkapkan pendapatnya di depan umum. Yaitu di depan adik kelas ataupun kakak kelas.

Para santri dituntut untuk dapat memecahkan beberapa masalah yang sering terjadi di tengah kehidupan masyarakat. Dimana sering kali banyak orang yang belum mengetahui hukum tertentu, apakah itu diperbolehkan atau tidak. Pada Bahtsul Masail kali ini. Para santri membahas berbagai persoalan mulai, thoharoh, mu'amalah, sholat dan lain lain. Sebagai referensi, para santri menggunakan beberapa kitab seperti Fathul Qorib, Fathul Muin, Fathul Wahhab, Al Asybah Wannadloir, Bughyah Al Mustarsyidin dan kitab-kitab fiqih lainya. ${ }^{15}$

Wawancara dengan ustadz Mashuri:

" kegiatan bahsul masail merupakan kegiatan latihan berbicara dan menggali hukum bagi para santri untuk kesiapan besoknya mereka balik ke masyatakat, didalamya juga mengajarkan santri untuk menghargai dan menghormati pendapat yang berbeda-beda dengan dalil yang sama kuat, tetapi semua berjalan dengan lancar, karena santri diajarkan oleh para guru bahwa perbedaan pendapat adalah pluralitas dari alloh sehingga tidak boleh memaksakan pendapat orang lain harus sama dengan diri kita, beliau juga menyampaikan jelas bahwa kegiatan bahsul masail mengandung niilai nilai pancasila yaitu dalam prinsip saling menghormati dan menghargai, dalam pancasila masuk dalam butir2 nilai pancasila dalam sila yang ke $3 "$.

Hasil wawancara diatas dapat disimpulkan, kegiatan Bahtsul Masail yang sifatnya non formal, membantu dan menunjang nilai nilai pancasila terhadap santtri, bukan

${ }^{15}$ Hasil wawancara dengan Ustad Ali Mashuri pada hari Sabtu tanggal 31 Oktober 2020 jam16.55 WIB di Pondok Pesantren Tremas 
secara teori lebih dalam praktek atau aplikasinya dalam metode kegiatanya.

2. Informal

a. Ngipa

Ngipa atau ngirit pajekan dalam bahasa resmi pondok disebut Diafah sudah berlangsung sejak dulu kala di Pondok Tremas. orang yang pertama kali memberi nama atau sebutan ngipah adalah KH. Imron Rosyadi dari Bangil Pasuruan. Ketika masih mondok di Tremas, beliau dikenal sebagai santri yang sangat humoris, dan dari kehumorisan beliaulah sebutan ngipa atau ngipah menjadi tradisi yang masih berlangsung di Pondok Tremas hingga kini Meski terlihat serupa namun sebenarnya sejarah ngipa dan dliyafah itu tidaklah sama. Istilah ngipa yang digunakan para santri sejak dulu itu muncul karena pada hari-hari besar Islam, para santri mendapatkan makanan gratis tanpa harus mengambil jatah dari pajekannya (tempat kost makan). Sedangkan diyafah adalah yang berasal dari bahasa arabyang dimunculkan oleh keluarga ndalem yang berarti penjamuan atau penghormatan.

Pada zaman dahulu, pelaksanaan ngipa atau dliyafah menjadi tanggung jawab PHBI. Namun karena semakin hari jumlah santri Tremas terus bertambah, dan dana PHBI tidak mencukupi lagi untuk melaksanakan tradisi itu, maka pelaksanaannya di ambil alih oleh keluarga ndalem dan dilaksanakan setiap khaul yang dimulai pada khaulnya mbah Kyai Dimyathi sekitar 68 tahun yang lalu. Pada saat ini sebutan ngipah telah meluas, tidak hanya terbatas makan gratis pada saat khaul yang berlangsung setahun sekali saja, tetapi juga digunakan untuk menyebut kegiatan makan gratis secara menyeluruh, kapanpun, dimanapun dan diselenggarakan oleh siapapun. ${ }^{16}$

Hasil wawancara dengan Ustadz Ridho:

${ }^{16}$ Wawancara Utad Ali Ridho, sabtu 31 oktober.16.55wib 
" ngipah adalah bentuk kegiatan informal bagi santri, terbukti dengan adanya ngipah seluruh santri tidak terlalu boros dalam hari itu, sehingga para santri bisa menabung, selain itu para kiyai mengajarkan juga betapa pentingnya rasa kekeluargaan, sama rasa dan sama rata, dalam penyediaan makanan ngipah, semuanya sama tidak ada yang dibeda bedakan, mau anak pejabat, kiyai, panglima dan sebagainya"

Narasi diatas menjelaskan, subtansi dari ngipa mengandung nilai-nilai pancasila, seperti sila yang ke 5 kemanusiaan yang adil dan beradab, ${ }^{17}$ butir2 sila ke 5 mengajarkan kepada seluruh rakyat indonesia untuk sama rasa dan sama rata, selaras dengan subtansi pengajaran informal yang di terapkan oleh pihak Pondok Pesantren Tremas Arjosari Pacitan Jawa Timur, dengan bentuk ngipa yang diadakan setiap memperingati haul para masyayikh.

Faktor Pendukung dan Kendala yang Dihadapi dalam Penanaman Nilai-nilai Pancasila dalam Pendidikan di Pondok Pesantren Tremas Arjosari Pacitan Jawa Timur

Pada saat suatu kegiatan akan dilangsungkan, tentunya sudah dipikirkan secara serius segala macam dampak positif maupun dampak negatif yang akan terjadi. Begitu pula dengan suatu rancangan penelitian. Ketika seorang peneliti akan mengadakan suatu penelitian, maka peneliti harus memikirkan pula faktor pendukung yang menunjang keberhasilan penelitiannya serta berbagai kendala yang mungkin akan mengahambat pelaksanaan dan mempengaruhi hasil penelitiannya.

Dalam penelitian tentang Penanaman Nilai-nilai Pancasila dalam Pendidikan di Pondok Pesantren Tremas arjosari Pacitan jawa timur terdapat pula faktor pendukung dan juga kendalayang dihadapi. Untuk lebih jelasnya akan dipaparkan seperti berikut ini.

Pelajar, 2009).

${ }^{17}$ NOOR MS BAKRY, PENDIDIKAN PANCASILA (Yogyakarta: Pustaka 
a) Peranan Para Pengajar sebagai Motivator dan Fasilitator dalam setiap Kegiatan yang Ada di Pondok Pesantren (Keteladanan Kyai) Keberadaan para pengajar di Pondok Pesantren merupakan salah satu faktor terpenting dalam menanamkan nilai-nilai pancasila. Peranan pengajar sebagai motivator dan juga sebagai fasilitator dalam setiap kegiatan yang ada di Pondok, membuat para santri memiliki peluang terbuka untuk mengembangkan dirinya. Kepedulian dan sikap ramah dari para pengajar dalam membagikan ilmu yang dimilikinya untuk para santri membuat para santri beranggapan bahwa pengajar itu bukan sekadar pengajar, akan tetapi sudah seperti sahabat atau konsultan bagi para santri.

Berikut ini petikan wawancara dengan salah satu santri putra bernama Aji di Pondok Pesantren Tremas Arjosari Pacitan Jawa Timur:

"Kalau secara pribadi, menurut saya peranan kyai itu penting sekali. Keteladanan Abah dan Umi yang seharusnya menjadi motivasi bagi para santri. Meskipun kadang kami mengeluhkan tentang fasilitas yang terbatas, tapi itu bukan masalah bagi kami. Kami masih bisa belajar langsung dari kiyai dan buk nyai serta pengajar yang lainnya. Keterbatas ilmu pengetahuan juga tidak menjadi masalah bagi kami, yang penting masih ada yang mengarahkan kami untuk mengetahui mana yang benar dan mana yang salah". ${ }^{18}$

Menjalani peran ganda sebagai motivator sekaligus sebagai fasilitator bukanlah suatu perkara yang mudah bagi para pengajar di Pondok Pesantren. Oleh para santri, para pengajar dianggap sebagai motivator bagi mereka. Ilmu yang mereka miliki merupakan motivasi bagi para santri untuk belajar. Sama halnya dengan peran pengajar sebagai motivator,

${ }^{18}$ Hasil wawancara dengan santri Aji pada hari Selasa tanggal 2 November 2020 jam 21.45 WIB di Pondok Pesantren Tremas 
peran pengajar sebagai fasilitator pun sangat penting. Tanpa adanya fasilitas yang diberikan oleh pengajar, maka para santri pun tidak akan bisa memperoleh ilmu. Oleh karena itu, dalam penanaman nilai-nilai pancasila di pondok Pesantren ini, peranan para pengajar diharapkan agar mempermudah pertumbuhan dan terwujudnya nilai-nilai pancasila dalam pendidikan di Pondok Pesantren Tremas Arjosari Pacitan Jawa Timur. ${ }^{19}$

b) Keinginan Para Santri untuk Belajar Lebih Banyak tentang nilai-nilai pancasila (Motivasi Santri)

Dorongan kuat dari masing-masing santri untuk mempelajari nasionalisme secara lebih mendalam menjadi hal yang sangat penting bagi pertumbuhan nilai-nilai pancasila di pondok Pesantren. Hal ini menjadi salah satu faktor pendukung yang kuat bagi keberhasilan penanaman nilai-nilai pancasila dalam pendidikan.

Menurut wawancara dengan salah satu santri di Pondok Pesanttren Tremas Arjosari Jawa Timur, seperti yang dinyatakan sebagai berikut:

"Pada dasarnya saya meyakini bahwa sebagian besar para santri di pondok Pesantren ini menginginkan adanya pembelajaran yang lebih mendalam mengenai nilai-nilai pancasila. Nilai-nilai pancasila yang kami ketahui selama ini mungkin masih dalam batasan minimal, tidak seperti di sekolahsekolah formal. Mempelajari, memahami, dan menanamkan nilai-nilai pancasila sebenarnya bermanfaat bagi para santri di sini. Apabila ada kesempatan bagi kami untuk mempelajarinya lebih dalam lagi, tentunya kami akan sa senang dan memberikan banyak manfaat bagi kemajuan pondok Pesantren ini. "2o

\footnotetext{
${ }^{19}$ Hasil wawancara dengan Ustad Ali mashuri pada hari Sabtu tanggal 31 oktober 2020 jam 16.01 WIB di Pondok Pesantren Tremas

${ }^{20}$ Hasil wawancara dengan santri Tiyan pada hari Selasa tanggal 2 November 2020 jam 22,30 WIB di Pondok Pesantren Tremas
} 
Berdasarkan hasil wawancara tersebut, dapat disimpulkan bahwa niat dan keinginan para santri untuk mempelajari dan menanamkan nilai-nilai pancsasila merupakan hal penting yang membantu pemaknaan dan tertanamnya nilai-nilai nasionalisme. Adanya niat dan keinginan akan mempermudah dalam penanaman nilai-nilai pancasila dalam pendidikan yang hampir luntur di era sekarang ini.

Berdasarkan hasil wawancara dan pengamatan yang dilakukan oleh peneliti, kendala-kendala yang dihadapi adalah sebagai berikut.

1) Peran Pengajar sebagai Motivator sekaligus Fasilitator Belum Terlaksana secara Maksimal Kurangnya dukungan dari para pengajar pada umumnya juga turut menghambat pemaknaan penanaman nilai-nilai nasionalisme. Tidak dapat dipungkiri bahwa sebagai suatu lembaga pendidikan nonformal, tentunya segala bentuk kegiatan juga harus mendapat dukungan dari pihak pengurus dan juga pengajar. Selain mengajar di Pondok Pesantren Tremas Arjosari Pacitan Jawa Timur, para pengajar juga bekerja pada siang hari. Selain itu juga terkadang parapengajar memiliki kepentinngan yang sifatnya mendadak dan penting, sehingga terkadang para pengajar dan pengurus tidak dapat menemani pada saat kegiatan-kegiatan tertentu. ${ }^{21}$

2) Munculnya Sikap Malas untuk Mempelajari nilai-nilai pancasila secara Lebih Mendalam Perasaan malas, jenuh, bosan tidak bisa dipungkiri lagi kedatangannya. Pada beberapa santri, hal ini mungkin saja terjadi. Adanya perasaan malas dan rasa tidak ingin tahu lebih banyak tentan nasionalisme juga muncul di kalangan para santri. Beberapa dari mereka sempat mengungkapkan keengganan untuk mempelajari nilai-nilai

${ }^{21}$ Hasil wawancara dengan Ustad Ali Ridho pada hari Sabtu tanggal 31 Oktober 2020 jam 17.02 WIB di Pondok Pesantren Tremas 
pancasila Menurut salah satu santri, dalam wawancaranya mengungkapkan seperti berikut in:

"Memahami nilai-nilai pancasila itu tidak mudah, apalagi jika harus mempelajarinya. Anak-anak yang ada di sekolah formal saja terkadang belum tentu bisa menerapkan nilainilai pancasila itu Apabila ditanya tentang pancasila itu jujur saja minat dan ketertarikan saya untuk mempelajari nilainilai pancasila itu masih belum muncul."

Berdasarkan kutipan wawancara terhadap salah satu santri tersebut, dapat dikatakan bahwa rasa malas dan rasa ketidak ingin tahuan itu adalah sesuatu yang tidak bisa dihindari ketika sedang berproses. Oleh karena itu, perasaan semacam itu menjadi kendala dalam Penanaman Nilai-nilai Pancasila dalam Pendidikan di Pondok Pesantren Tremas Arjosari Pacitan Jawa Timur.

\section{Simpulan}

Penanaman Nilai-nilai Pancasila dalam Pendidikan di Pondok Pesantren Tremas Arjosari Pacitan Jawa Timur yang diwujudkan dalam beberapa bentuk kegiatan diantaranya Pengajian Kitab Bandongan, Bahtsul Masa"Il roan, kegiatan upacara, pramuka, ngipa dan lain sebagainya, semuanya memiliki nilai-nilai pancasila seperti kebersamaan, menghormati, menghargai, sama rasa dan mencintai NKRI.

Faktor pendukung dalam Penanaman nilai-nilai Pancasila dalam Pendidikan di Pondok Pesantren Tremas Arjosari Pacitan jawa Timur meliputi: peran pengajar sebagai motivator dan fasilitator yaitu berupa kesungguhan dan keteladanan dalam mengajar dan mendidik, motivasi dari dalam diri santri untuk mengetahui serta semangat untuk belajar, interaksi dengan masyarakat sekitar pondok pesantren dengan mengaplikasikan komuniasi yang baik , serta sarana dan prasarana yang menunjang untuk proses Penanaman nilai-nilai Pancasila dalam Pendidikan di Pondok Pesantren Tremas Arjosari Pacitan Jawa Timur 
Kendala yang dihadapi dalam Penanaman Nilai-nilai Pancasila dalam Pendidikan di Pondok Pesantren Tremas Arjosari Pacitan Jawa Timur peran pengajar sebagai motivator dan fasilitator yang belum terlaksana dengan maksimal seperti sibuk dan tidak fokusnya pengajar , kurangnya motivasi belajar dalam diri santri untuk memahami nilai-nilai pancasila dan tidak semangat untuk belajar, kurangnya kerja sama antara pihak pondok dengan pihak lain (interaksi dengan masyarakat) menjalin komunikasi yang baik.

\section{Saran}

1. Para pengajar dan para santri di Pondok Pesantren Tremas Arjosari Pacitan Jawa Timur sebaiknya terus memperdalam pengetahuan tentang nilai-nilai pancasila dengan segala seluk beluknya, agar lebih mudah dalam penanaman nilai nilai pacasila

2. Bagi santri Seluruh warga Pondok Pesantren Tremas Ajosari Pacitan Jawa Timur sebaiknya tetap membiasakan dan menjalankan kegiatan -kegiatan yang merupakan wujud penananaman nilai nilai pancasila dalam pendidikan di Pondok Pesantren Tremas Arjosari Pacitan Jawa Timur, karena melalui kegiatan-kegiatan tersebut terhadap penanaman nilai-nilai pancasila akan terasa lebih mudah

3. Bagi Guru Para pengajar dan para santri hendaknya senantiasa memaknai dan menanamkan nilai-nilai pancasila dalam lingkup kehidupan sehari-hari, agar nilai-nilai pancasila tidak luntur di masa mendatang.

4. Bagi peneliti selanjutnya yang ingin melakukan dan mengembangkan penelitian ini, diharapkan untuk melakukan penelitian serupa dengan menggunakan subyek yang berbeda. Atau mungkin dengan objek yang berbeda pula agar semakin mengembangkan penelitian yang membahas penanaman nilai-nilai pancasila dalam 
pendidikan di Pondok Pesantren Tremas Arjosari Pacitan Jawa Timur.

\section{Daftar Pustaka}

Baharuddin. (2014). Pendidikan dan Psikologi Perkembangan.

Yogyakarta: Ar-Ruzz Media.

Bakry, Noor Ms. Pendidikan Pancasila. Yogyakarta: Pustaka Pelajar, 2009.

Burhanudin salam, Filsafat Pancasialisme. (1994). Bandung: Rineka Cipta.

Haryono. (2014). Ideologi Pancasila: Roh Progesif Nasinalisme Indonesia. Malang: Imtrans Pubishing.

Humaidi, A. (2019). Bargaining Pesantren di Era Revolusi Industri 4.o. Prosiding Nasional, 2 (November), 255-268.

Hafidz Muftisany. "Sorogan Dan Bandongan Metode Khas Pesantren.” Republika. April 8, 2016. https://republika.co.id/berita/o5ar464/sorogan-danbandongan-metode-khas-pesantren.

Kaelan. (1998). Pendidikan Pancasila Yuridis Kenegaraan. Yogyakarta: Paradigma Ofset.

Mastuhu. (1995). Dinamika Sistem Pendidikan Pesantren. Jakarta: INIS.

M Fathurrozi. "Bahtsul Masail; Pendapat Siapa Yang Paling Kuat." Pondoktremas.com, n.d. https://pondoktremas.com/bahtsulmasail-pendapat-siapa-yang-paling-kuat/.

MS, A. A., Suntoro, I., \& Yuzan, H. (2018). internalisasi nilai-nilai Nasionalisme Di Pondok Pesantren. Jurnal Kultur Demokrasi, $7(5)$. 
Pradana, F. (2014). Implementasi Nilai-Nilai Pancasila Sila Kemanusiaan Yang Adil Dan Beradab Dalam Kehidupan Santri Di Pondok Pesantren (Studi Kasus Pondok Pesantren Muhammadiyah Desa Lemah Gunung Kecamatan Kota Kabupaten Kudus Tahun 2014. Universitas Muhammadiyah Surakarta.

Qodir, Z. (2014). RADIKALISME AGAMA DI INDONESIA Pertautan Ideologi Politik Kontemporer dan Kekuasaan. Yogyakarta: Pustaka Pelajar.

Rois, N. (2017). Penanaman Nilai-nilai Nasionalisme dalam Pendidikan Pesantren Miftahul Ulum kabupaten Semarang. Jurnal Progress, 5(1).

S, M. A. H. (n.d.). makalah radikalisme. Retrieved from 2015 website: aribherziozo696.blogspot.co.id.

Sakti, (Muhammad Bimo, Suntoro, I., \& Nurmalisa, Y. (2018). Peranan Pesantren Dalam Menumbuhkan Wawasan Kebangsaan Kepada Santri (Studi Kasus Di Pondok Pesantren Darul Ulum Kecamatan Seputih Banyak). Jurnal Kultur Demokrasi, 7(4).

WJ, \& Purwadarminta, S. (1984). Kamus Besar Bahasa Indonesia. Jakarta: Balai Pustaka.

Yusuf, F. (2011). Penanaman Nilai-nilai Nasionalisme dalam Lingkup Kehidupan Sehari-hari di Pondok Pesantren Darul Falah Desa Jekulo Kecamatan Jekulo Kabupaten Kudus. Universitas Negeri Semarang. 